\title{
Identification and Characterization of Cassava Mosaic Begomoviruses in Non-crop Plants from Unguja and Pemba Islands
}

\author{
Joseph A. Mwakosya, ${ }^{1,2}$ Gladness E. Temu ${ }^{2}$ and Joseph C. Ndunguru ${ }^{3}$ \\ ${ }^{I}$ Mazwi Secondary School, P. O. Box 632 Sumbawanga, Tanzania \\ E-mail: mwakosyajoseph@yahoo.com \\ ${ }^{2}$ Department of Molecular Biology and Biotechnology, University of Dar es Salaam, P. O. Box \\ 35091 Dar es Salaam, Tanzania \\ E-mail: gladye2000@yahoo.com \\ ${ }^{3}$ Tanzania Agricultural Research Institute (TARI), Selian-Arusha, Tanzania \\ E-mail: jndunguru2003@yahoo.co.uk
}

Received 4 Jul 2021, Revised 10 Oct 2021, Accepted 25 Oct 2021, Published Dec 2021

DOI: https://dx.doi.org/10.4314/tjs.v47i5.31

\begin{abstract}
Cassava mosaic disease caused by cassava mosaic begomoviruses (CMBs) remains one of the major constraints to cassava production since it causes yield losses up to $100 \%$. Researches showed that some of CMBs infecting cassava plants may be coming from non-crop plants. This study intended to identify and characterize CMBs isolated from non-crop plant species in Unguja and Pemba Islands. A total of 108 viral symptomatic and asymptomatic non-crop leaf samples were collected using stratified sampling. DNA was extracted by using CTAB protocol followed by polymerase chain reaction using universal and specific primers for cassava mosaic begomoviruses identification. Results showed that, among eleven samples that were amplified, four were African cassava mosaic viruses (ACMV) and seven were East African cassava mosaic viruses (EACMV). DNA sequencing by Sanger method showed 97-99\% similarities with isolates of ACMV and EACMV reported elsewhere in Africa. Using RbcL and MatK plant barcode genes, Datura stramonium, Solanum melongena and Solanum incanum were found associated with ACMV, while Senna occidentalis, Sida acuta and Ricinus communis harboured EACMV. These findings are a key in understanding the epidemiology of cassava mosaic disease and are potential in the development of sustainable management strategies for this disease.
\end{abstract}

Keywords: Begomoviruses, Cassava mosaic disease, East African cassava mosaic virus, Non crop plants.

\section{Introduction}

Cassava (Manihot esculenta Crantz) is an important staple food crop, which provides an affordable source of carbohydrates to over 800 million people around the world (Legg et al. 2014). It is categorized as a food security crop, especially in Sub Saharan Africa. About $70 \%$ of the cassava produced worldwide is used for human consumption either directly after cooking or in processed forms, while the remaining $30 \%$ is used for animal feed and industrial products such as starch, glucose and alcohol (Legg et al. 2014). About 277 million tons of cassava are produced worldwide cultivated on 23 million ha (FAOSTAT 2019). Africa produces 157 million tons of cassava on 17 million ha of land with Nigeria being the leading country in the world, which produces about 47 million tonnes (FAOSTAT 2019). Tanzania is the sixth cassava producer in Africa and the leading in East Africa (FAOSTAT 2019). In Tanzania, cassava is 
grown on 761100 ha with an average output of 5.58 million tonnes; and about 8 tonnes are produced per ha (Sewando 2012). Furthermore, $91.1 \%$ of cassava is produced in Tanzania Mainland, while the remaining $8.9 \%$ is produced in Zanzibar [Unguja and Pemba Islands] (Shoka 2015). In Zanzibar, the highest cassava production was reported in North Pemba region (16,865 tons; $30.2 \%)$ followed by South Pemba (15,438 tons; $27.2 \%)$ and North Unguja (13,119 tons; $23.5 \%$ ), while the lowest production was in Urban West [3,374 tons; 6.0\%] (Shoka 2015).

Cassava mosaic disease (CMD) caused by cassava mosaic begomoviruses (CMBs) is a threat to cassava production in Africa, causing yield losses of about 21.8 to 34.8 million tons per annum (Bisimwa et al. 2012). In East and Central Africa, CMD has led to the loss of 13 million of metric tonnes annually (Varsani et al. 2014). In Tanzania, the virus causes yield losses from insignificant to $100 \%$, depending on cassava variety, time of infections, type of virus and cultural practices (Kidulile et al. 2018). The disease is transmitted by the whitefly (Bemisia tabaci) (Ndunguru et al. 2005, Legg et al. 2014). Cassava mosaic disease was reported for the first time in Tanganyika (now Tanzania) in 1894 on the foothills of Usambara Mountains (Storey and Nichols 1938). Since cassava was introduced to Africa from Southern and Central America where CMD does not exist, it is suggested that cassava must have acquired CMBs from noncrop plants (Legg et al. 2014). For instance, Kyalo et al. (2017) identified a begomovirus from Deinbollia borbonica (dune soapberry) that is highly genetically identical to CMBs found in Kenya and Tanzania.

Begomoviruses have a wide host range causing yield losses to many important crops such as eggplants, tomatoes, cassava, beans, potatoes, cotton, squash and watermelons (Bonfim et al. 2007). It is also known that, some non-crop plant species serve as alternative hosts for the CMBs (Marwal et al. 2014). Non-crop plants are plants which are not cultivated and are not under direct human control (Power and Mitchell 2004). Various non-crop plants have been reported to harbour CMBs (Bock et al. 1981, Bock and Woods 1983, Burban et al. 1992, Bock 1994, Ogbe et al. 2006, Alabi et al. 2008, Kyalo et al. 2017). Therefore, due to the wide host range of CMBs, these viruses can be transmitted from non-crop plants to cassava plants and hence may lead to the spread of the CMD (Bisimwa et al. 2012). Thus, identification of CMBs in non-crop plants is important since the knowledge on the source of the virus inoculum will lead to formulation of effective CMD management strategies. Although many reports on molecular characterization and identification of CMBs exist, many of these reports were done in cassava and very few in the non-crop plants. Therefore, this study intended to identify and characterize CMBs isolated from non-crop plant species in Unguja and Pemba Islands of the United Republic of Tanzania, using rolling cycle amplification (RCA), polymerase chain reaction (PCR) and Sanger sequencing. The tools used in this study for identification were reported earlier as among the efficient methods for identification of CMBs in both cassava and non-crop plants (Udayashankar et al. 2012, Alemu 2015).

\section{Materials and Methods}

This study was carried out in selected parts of all districts of Unguja (North A, North B, Urban, West, South and Central) and Pemba (Micheweni, Wete, Chake Chake and Mkoani) Islands (Figure 1). The provinces were selected for the surveys due to a very long history of existence with great influence from Arabs and European traders who imported different plants and plant products such as cloves, pepper, cinnamon, ginger and nutmeg to Unguja and Pemba Islands (Bosque-Perez and Eigenbrode 2011). Through this way, there are high possibilities of introducing vectors and viruses that infect both cassava and non-crop plants. These islands also were selected due to the reports on CMD prevalence, where by the overall CMD incidence in the fields was up to $71 \%$ (NSCACS 2012, Shoka 2015). 


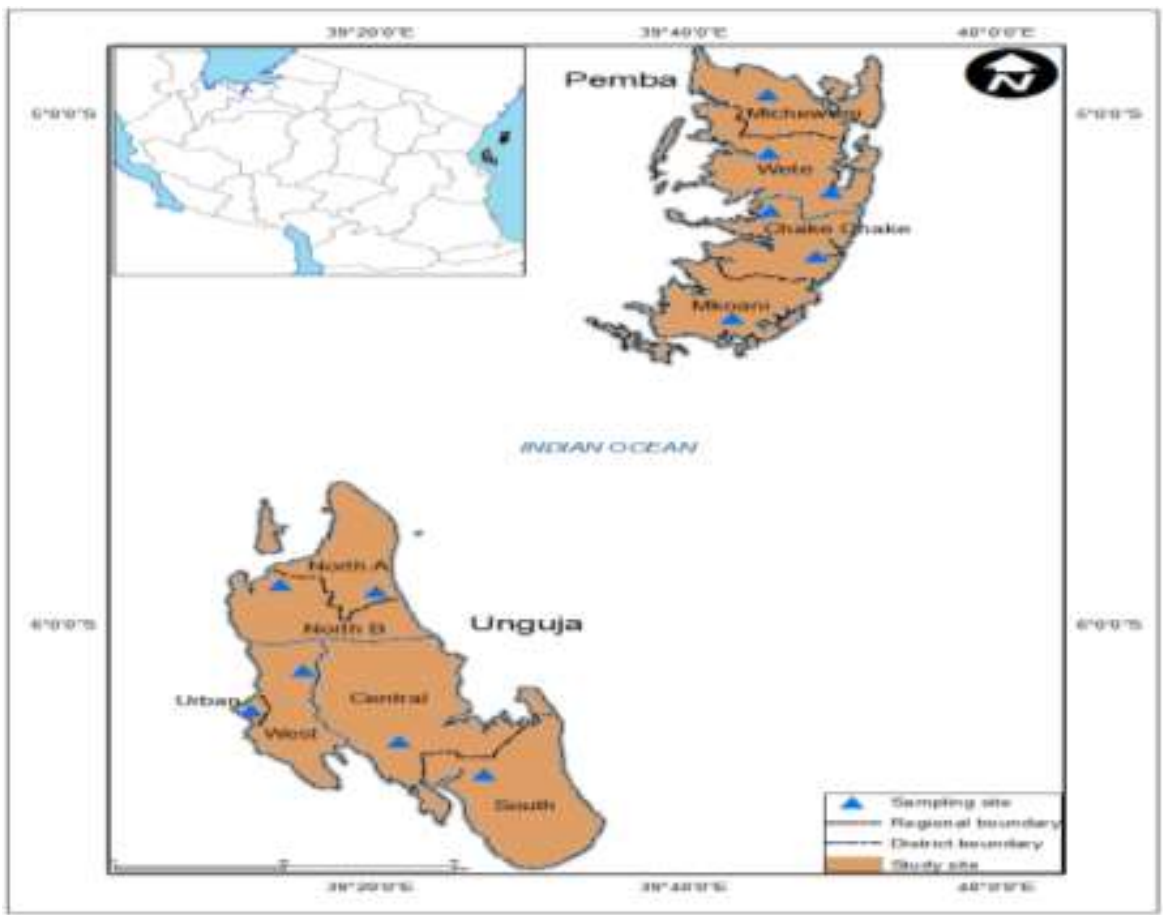

Figure 1: The map of part of Tanzania showing the study sites in Unguja and Pemba Islands.

Leaf samples were collected from several places with different ecology in August 2018. The common habitats from which the leaf samples were collected included disturbed forest, undisturbed forest, and woodland, garden weed, bush land, dry grassland, forests, seasonally flooded grasslands and shallow moist soils. Stratified sampling design was employed in establishment of twelve plots (six from Unguja and six from Pemba Island). One plot was established in each district in both Unguja and Pemba Islands except for Chake chake and Wete District where two plots were established in each district because of having larger area than other districts in Pemba Island (McIntyre and Shand 2006). In each plot, 9 young full expanding top leaves from diverse plant species showing virus-like symptoms were carefully sampled along plot diagonals following an " $X$ " pattern as previously described by Sseruwagi et al. (2004). The viral-like symptoms found in the fields were diverse, therefore; symptom descriptions were recorded and scored on a scale of 1-5 (five scales) as reported by Hahn et al. (1980).
Only symptomless leaf samples were collected from sites in which no viral-like symptoms were observed. A total of 108 non-crop leaf samples from symptomatic and asymptomatic plants were collected from selected areas. The collected leaf samples were placed in envelopes and flipchart paper sheets and pressed on herbarium and transported to molecular disease diagnostic laboratory at Tanzania Agricultural Research Institute (TARI) - Mikocheni, Tanzania for further analysis.

\section{DNA extraction and polymerase chain reaction}

DNA was extracted using Cetyl-Trimethyl Ammonium Bromide (CTAB) protocol adopted from Lodhi et al. (1994). Determination of concentration and purity of the DNA was performed using a nanodrop spectrophotometer (Thermo Scientific Nanodrop 2000) at an absorbance of (A 260/280) according to the manufacturer's instructions. PCR using universal primers (EAB555F/R and JSP 001/002 F/R) (Table 1) were used in the screening of seven common 
CMBs species that are known to occur in Africa, namely African Cassava Mosaic Virus (ACMV), East African Cassava Mosaic Virus (EACMV), East Africa Cassava Mosaic Ugandan Variant (EACMV-UG2), East African Cassava Kenya Mosaic Virus (EACMV-KE), East African Cassava Mosaic Cameroon Virus (EACMCV), East African Cassava Mosaic Zanzibar Virus (EACMZV) and South African Cassava Mosaic Virus (SACMV). For the purpose of minimizing costs and time, from the 108 collected samples, 4 to 5 DNA samples were pooled to form one sample, and therefore forming a total of 22 pools. Pooled samples which tested positive were opened and detection was done on individual DNA sample using CMBs specific primers to identify individual positive samples for CMB (Table 1).

PCR with specific primers for each CMB was done following procedures described by Fondong et al. (2000). For identification of non-crop plants species harbouring CMBs, eleven DNA samples which tested positive for CMBs were amplified by using RbcL and MatK gene primers (Table 2) as described by Cuénoud et al. (2002) and Kress et al. (2009).

Table 1: List of primers used for detection of CMBs using PCR

\begin{tabular}{|c|c|c|c|c|c|c|}
\hline Sn & Primer name & Sequence $\left(5^{\prime} \rightarrow 3^{\prime}\right)$ & $\begin{array}{l}\text { Virus } \\
\text { species }\end{array}$ & $\begin{array}{l}\text { Target } \\
\text { region }\end{array}$ & $\begin{array}{l}\text { Expected } \\
\text { size (nt) }\end{array}$ & References \\
\hline \multirow[t]{2}{*}{1} & EAB555-F & $\begin{array}{l}\text { TACATCGGCCTTTGAGTC } \\
\text { GCATGG }\end{array}$ & EACMV & $\mathrm{AV} 1 / \mathrm{CP}$ & 554 & $\begin{array}{l}\text { Pita et al. } \\
2001\end{array}$ \\
\hline & EAB555-R & $\begin{array}{l}\text { CTTATTAACGCCTATATA } \\
\text { AACACC }\end{array}$ & EACMV & $\mathrm{AV} 1 / \mathrm{CP}$ & 700 & $\begin{array}{l}\text { Pita et al. } \\
2001\end{array}$ \\
\hline \multirow[t]{2}{*}{2} & JSP001-F & $\begin{array}{l}\text { ATGTCGAAGCGACCAGG } \\
\text { AGAT }\end{array}$ & ACMV & $\mathrm{AV} 1 / \mathrm{CP}$ & $540-560$ & $\begin{array}{l}\text { Fondong et } \\
\text { al. } 2000\end{array}$ \\
\hline & JSP002-R & $\begin{array}{l}\text { TGTTTATTAATTGCCAAT } \\
\text { ACT }\end{array}$ & ACMV & $\mathrm{AV} 1 / \mathrm{CP}$ & $540-560$ & $\begin{array}{l}\text { Fondong } \\
\text { al. } 2000\end{array}$ \\
\hline \multirow[t]{2}{*}{3} & ACMV-F & $\begin{array}{l}\text { CTCAGATGTCAAGTCCT } \\
\text { ATC }\end{array}$ & ACMV & $\mathrm{AV} 1 / \mathrm{CP}$ & 435 & Aloyce 2013 \\
\hline & ACMV-R & ATTGTGTGGGCCTAAAG & ACMV & AV1/CP & 435 & Aloyce 2013 \\
\hline \multirow[t]{2}{*}{4} & EACMV-F & $\begin{array}{l}\text { GCGTAAATGAGGATGAT } \\
\text { AAG }\end{array}$ & EACMV & $\mathrm{AV} 1 / \mathrm{CP}$ & 435 & Aloyce 2013 \\
\hline & EACMV-R & GGGTTTGCAGAGAACTA & EACMV & $\mathrm{AV} 1 / \mathrm{CP}$ & 435 & Aloyce 2013 \\
\hline \multirow[t]{2}{*}{5} & EACMZV-F & $\begin{array}{l}\text { CCAGGTCGAAGAATCGC } \\
\text { TTA }\end{array}$ & EACMZV & AV1/CP & 575 & Aloyce 2013 \\
\hline & EACMZV-R & $\begin{array}{l}\text { AGGTGTCTCCAATTGCTC } \\
\text { TC }\end{array}$ & EACMZV & $\mathrm{AV} 1 / \mathrm{CP}$ & 575 & Aloyce 2013 \\
\hline \multirow[t]{2}{*}{6} & EACMCV-F & $\begin{array}{l}\text { GGTAATGGGTTTAAGGA } \\
\text { CTGGT }\end{array}$ & EACMCV & $\mathrm{AV} 1 / \mathrm{CP}$ & 305 & Aloyce 2013 \\
\hline & EACMCV-R & $\begin{array}{l}\text { CCTGGTTAGACAACTGC } \\
\text { ATATT C }\end{array}$ & EACMCV & $\mathrm{AV} 1 / \mathrm{CP}$ & 305 & Aloyce 2013 \\
\hline \multirow[t]{2}{*}{7} & EACMKV-F & $\begin{array}{l}\text { TTGTCCTCCTCGAGCAG } \\
\text { ATCGTC }\end{array}$ & EACMKV & $\mathrm{AV} 1 / \mathrm{CP}$ & 338 & Aloyce 2013 \\
\hline & EACMKV-R & $\begin{array}{l}\text { AAGTCCTATATGGACAA } \\
\text { GGAC }\end{array}$ & EACMKV & $\mathrm{AV} 1 / \mathrm{CP}$ & 338 & Aloyce 2013 \\
\hline \multirow[t]{2}{*}{8} & EACMMV-F & $\begin{array}{l}\text { GTGCCCTGTTCTTCACGG } \\
\mathrm{T}\end{array}$ & EACMMV & AV1/CP & 435 & Aloyce 2013 \\
\hline & EACMMV-R & $\begin{array}{l}\text { ACCTAGACGAGGACAAG } \\
\text { AATTCC }\end{array}$ & EACMMV & $\mathrm{AV} 1 / \mathrm{CP}$ & 435 & Aloyce 2013 \\
\hline \multirow[t]{2}{*}{9} & $\begin{array}{l}\text { EACMV- } \\
\text { UG2-F }\end{array}$ & GGGTTTGCAGAGAACTA & $\begin{array}{l}\text { EACMV- } \\
\text { UG2 }\end{array}$ & $\mathrm{AV} 1 / \mathrm{CP}$ & 544 & $\begin{array}{l}\text { Ndunguru et } \\
\text { al. } 2005\end{array}$ \\
\hline & $\begin{array}{l}\text { EACMV- } \\
\text { UG2-R }\end{array}$ & $\begin{array}{l}\text { TAGAAGGTGATAGCCGT } \\
\text { A }\end{array}$ & $\begin{array}{l}\text { EACMV- } \\
\text { UG2 }\end{array}$ & $\mathrm{AV} 1 / \mathrm{CP}$ & 544 & $\begin{array}{l}\text { Ndunguru et } \\
\text { al. } 2005\end{array}$ \\
\hline \multirow[t]{2}{*}{10} & SEACMV-F & $\begin{array}{l}\text { GCTGTGTCCCCATTGTCC } \\
\text { AAGG }\end{array}$ & SEACMV & AV1/CP & 500 & $\begin{array}{l}\text { Fondong et } \\
\text { al. } 2000\end{array}$ \\
\hline & SEACMV-R & $\begin{array}{l}\text { CCTTTATTAATTTGTCAC } \\
\text { TC }\end{array}$ & SEACMV & $\mathrm{AV} 1 / \mathrm{CP}$ & 500 & $\begin{array}{l}\text { Fondong et } \\
\text { al. } 2000\end{array}$ \\
\hline
\end{tabular}




\section{Nucleotide sequencing and sequence analysis}

Obtained PCR products were sent to Inqaba Biotech Pretoria, South Africa for Sanger sequencing technique (Sanger et al. 1977). Each sample was sequenced twice, using forward and reverse primer. Forward and reverse nucleotide sequences of both CMBs and non-crop plant species were assembled and aligned by using the CLUSTALW programme found in MEGA 6 software as described by Thompson et al. (1994). The nucleotides were edited using BioEdit to remove noisy regions and thereafter, the edited sequences were blasted to compare with that from the National Centre for Biotechnology Information (NCBI) database using BLASTn.

\section{Phylogenetic analysis}

Three top sequences of CMBs and noncrop plant obtained from the blast results, with the highest similarity percentage were selected for phylogenetic analysis. The multiple sequence alignment of isolates obtained from the present study with the reference strains retrieved from the Genbank was done by using CLUSTALW. Then a phylogenetic tree was created by using the MEGA 6 Version 6 (Tamura et al. 2013). Phylogenetic tree was constructed by using maximum likelihood method. A bootstrap analysis was performed using 100 re-sampled data as reported by Felsenstein (1985).

Table 2: Primers used for identification of non-crop plants harbouring CMBs

\begin{tabular}{|c|c|c|c|c|}
\hline Region & $\begin{array}{l}\text { Name of } \\
\text { primer }\end{array}$ & Primer sequence $\left(5^{\prime} \rightarrow 3^{\prime}\right)$ & References & $\begin{array}{l}\text { Expected } \\
\text { product } \\
\text { length }\end{array}$ \\
\hline \multirow[t]{2}{*}{ MatK } & Kim_3F & $\begin{array}{l}\text { CGTACAGTACTTTTGTGTTTA } \\
\text { CGAG }\end{array}$ & $\begin{array}{l}\text { Cuénoud et al. } \\
2002\end{array}$ & 600 \\
\hline & Kim_1R & $\begin{array}{l}\text { ACCCAGTCCATCTGGAAATCT } \\
\text { TGGTTC }\end{array}$ & $\begin{array}{l}\text { Cuénoud et al. } \\
2002\end{array}$ & 600 \\
\hline \multirow[t]{2}{*}{$R b c L$} & $r b c L a \_\mathrm{F}$ & $\begin{array}{l}\text { ATGTCACCACAAACAGAGACT } \\
\text { AAAGC }\end{array}$ & Kress et al. 2009 & 600 \\
\hline & $r b c L a \_\mathrm{R}$ & GAAACGGTCTCTCCAACGCAT & Kress et al. 2009 & 600 \\
\hline
\end{tabular}

\section{Results}

\section{Viral-like symptoms observed in the field}

The viral-like symptoms of the collected leaf samples ranged from mild to severe.
Observed symptoms included, yellowing, mosaic, leaf rolling, stunted plants and curling leaves (Figure 2).

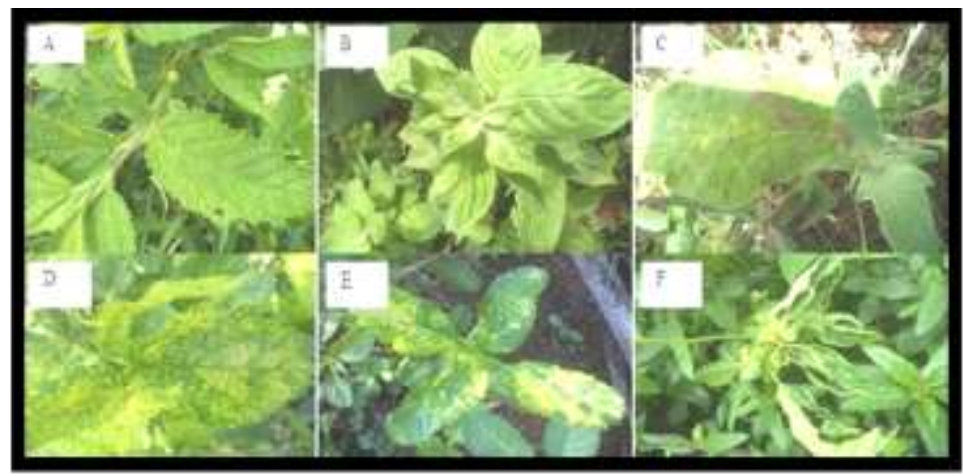

Figure 2: Virus like symptoms observed on representative non-crop plant leaves. A to E show yellowing; B and E stunted plants; and $\mathrm{F}$ shows both yellowing and leaf curling. 


\section{PCR, blastn and clustering analysis for CMBs}

Out of 108 leaf samples, only 11(10.19\%) samples yielded PCR products (Figure 3) using both universal (JSP001/JSP002F/R and
EAB555F/R) and specific (ACMVF/R and EACMVF/R) primers (Table 1). Among the eleven amplified samples, four were ACMV (Figure 3A), while seven were EACMV (Figure $3 \mathrm{~B}$ ).

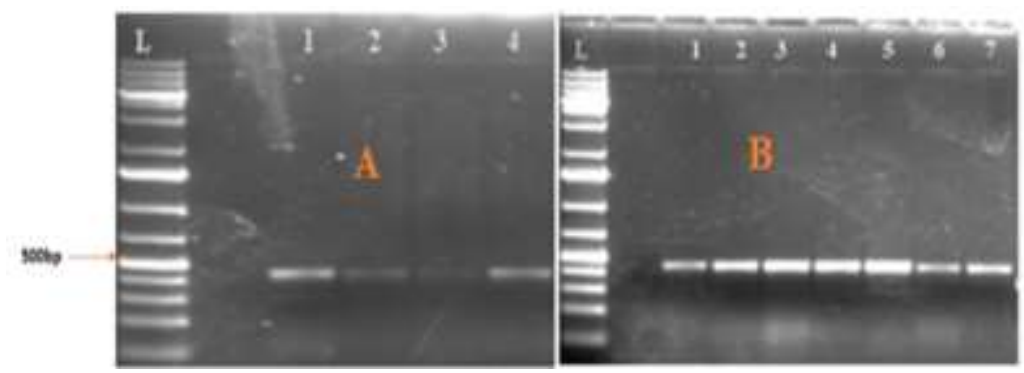

Figure 3: Agarose gel electrophoresis using specific primers for A: ACMV; B: EACMV; L: DNA Ladder and numbers on the lanes represent sample number. The expected PCR product was $435 \mathrm{bp}$.

Nucleotide sequence analysis of the coat protein of both ACMV and EACMV obtained from Sanger sequencing technique showed high (97 to 99\%) percentage similarity with other isolates of ACMV and EACMV.
Phylogenetic tree of both CMBs (ACMV and EACMV) (Figures 4 and 5) showed clustering in relation to their similar sequences retrieved from the NCBI database.

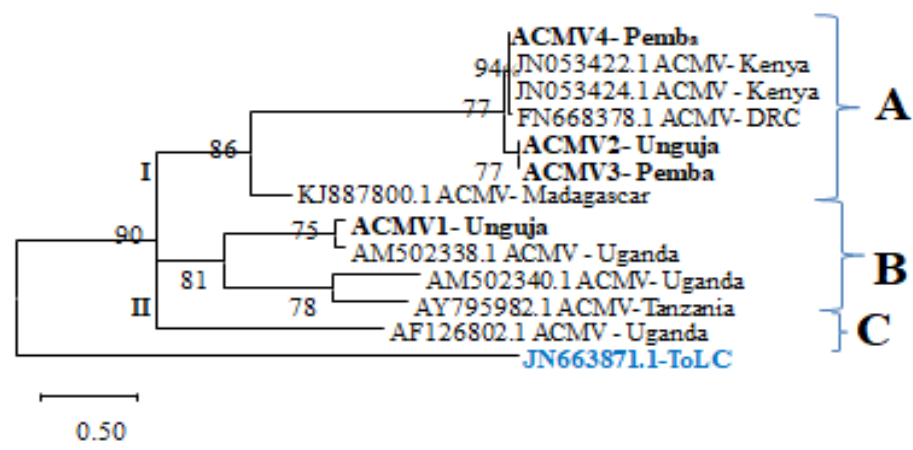

Figure 4: Phylogenetic tree constructed using Maximum Likelihood Method based on the coat protein region of ACMV isolates. The significance of the nodes was estimated using 100 bootstraps. Isolates from this study are in bold and those with accession numbers are from the NCBI database. Tomato leaf curl virus (ToLCV) was used as the out-group to root the tree. The scale bar indicates 0.5 substitutions. 


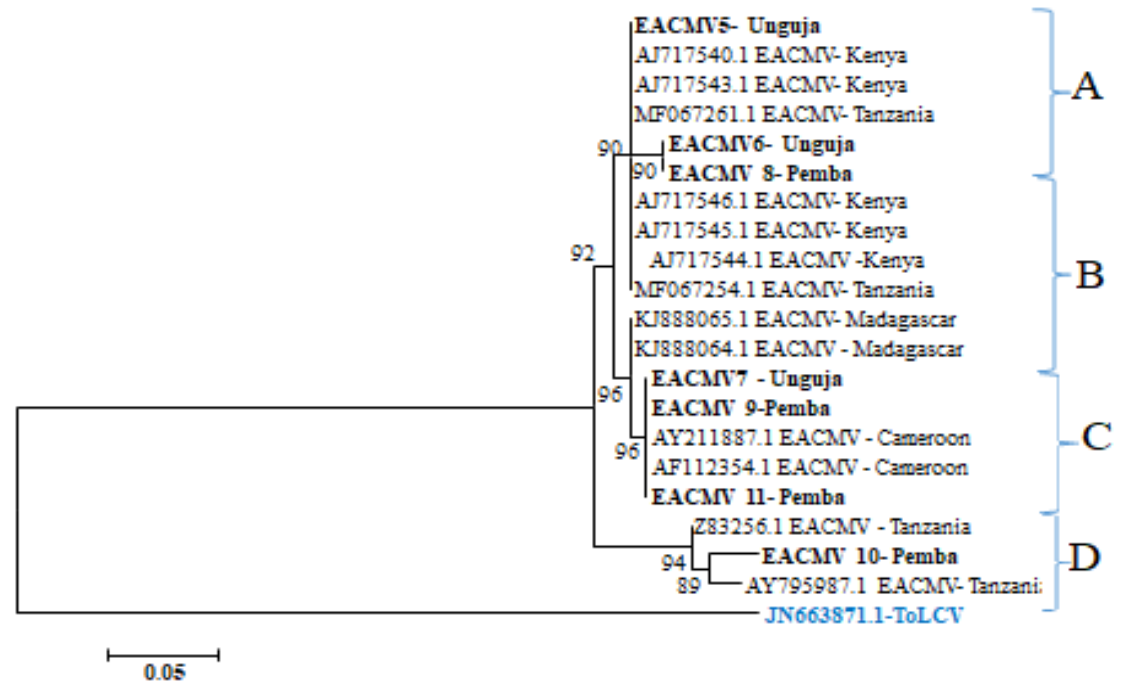

Figure 5: Phylogenetic tree generated using Maximum Likelihood Method available in MEGA6, based on the nucleotide sequences of the partial coat protein coding region of EACMV from Unguja and Pemba Islands isolates (bold) and the sequences drawn from the NCBI database. Bootstrap values were generated from 100 replicates. Tomato leaf curl virus (ToLCV) was used as the out-group and the scale bar indicates 0.05 substitutions.

\section{PCR, blastn and clustering analysis for non- crop plants}

PCR was positive for all 11 non-crop plants amplified with Rbcl primer while with MatK primer, 10 samples were positively amplified (Figure 6).

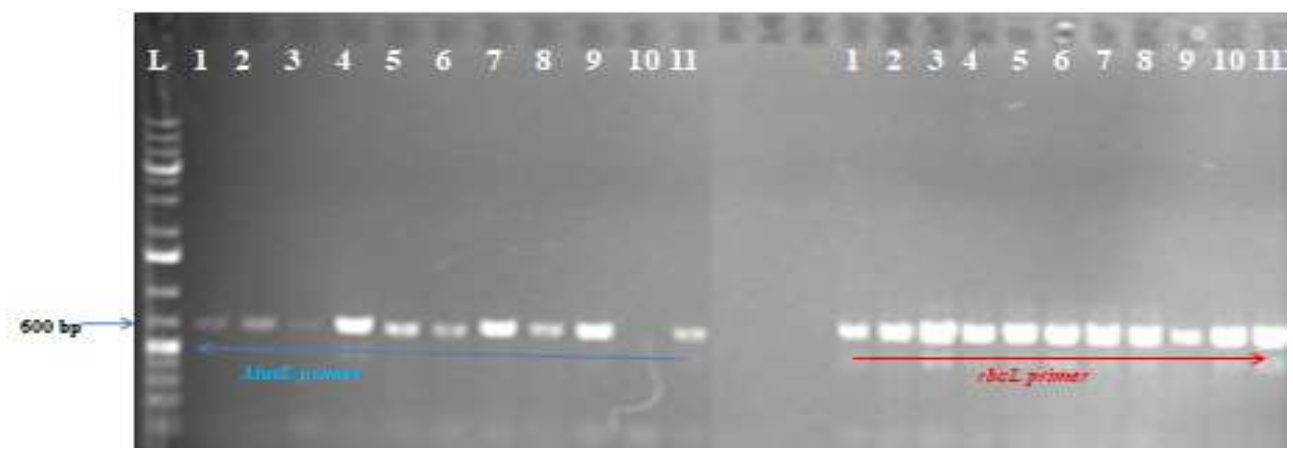

Figure 6: Agrose gel electrophoresis using the MatK and Rbcl barcode genes showing bands of the expected size (600bp). L represents $1 \mathrm{~Kb}$ DNA ladder (Fermentas); numbers 1 to 11 indicate samples tested.

The non-crop plant species harbouring the ACMV and EACMV shared sequence identity of 99 to $100 \%$ with the sequences of known non-crop plant species. Datura stramonium, Solanum melongena and $S$. incanum all from the family Solanaceae harboured ACMV; while Senna occidentalis (Fabaceae), Sida acuta (Malvaceae) and Ricinus communis (Euphorbiaceae) harboured EACMV. Phylogenetic tree of non-crop plants with their closest genus members are shown in Figure 7. 


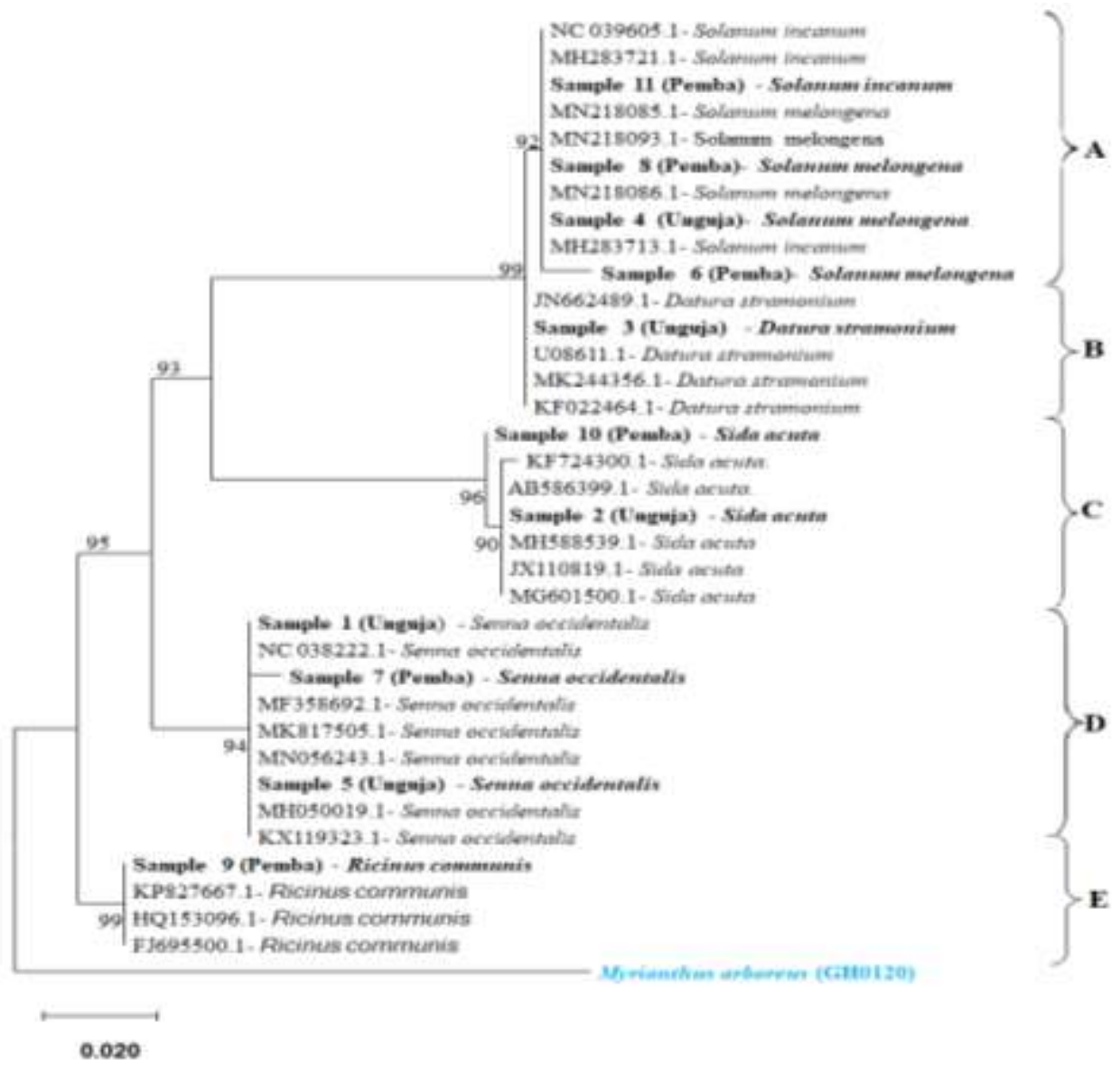

Figure 7: Phylogenetic tree generated using Maximum Likelihood Method available in MEGA6, showing the relationships between sequences of non-crop plant isolates from Unguja and Pemba Islands (in bold) with isolates drawn from the NCBI database (shown with GenBank accession numbers). Myrianthus arboreus was used as an out-group. Bootstrap analysis was performed using 100 replications.

\section{Discussion}

The leaf samples of non-crop plants collected in the present study showed different ranges of viral-like symptoms. The varieties of symptoms may be caused by various factors, including virus titre, the host's physiological state and environmental conditions. These observations agreed with the findings of Eni and Fasasi (2013) who reported a range of symptoms in non-crop plants infected by ACMV and EACMV. EACMV was the more common virus detected in Unguja and Pemba Islands than ACMV. The possible explanation can be due to high distributions of EACMV than ACMV in East African countries and especially along the coastal areas (Legg and Raya 1998, Ndunguru et al. 2005). This finding is similar to the findings reported by Berrie et al. (2001) that ACMVs are more common in the Western, Central and Southern Africa, while EACMVs are prominent in East African countries especially Kenya, Uganda and Tanzania.

Although samples representing different virus disease-like symptoms were collected, 97 (89.81\%) symptomatic non-crop plants tested negative for CMBs by both PCR and Sanger sequencing. The high percentage of negative tests for CMBs from the symptomatic non-crop plants in the present study is not a new scenario since other 
researchers have also reported similar high percentage of negative tests for CMBs from the symptomatic non-crop plants (Eni and Fasasi 2013, Marwal et al. 2014). The virallike symptoms observed earlier in the field can be caused by other plant viruses such as RNA plant viruses, DNA viruses apart from CMBs or environmental factors. In addition, it was also reported by Donaire et al. (2009) and Kreuze et al. (2009) that the absence of CMBs on leaves with virus-like symptoms may possibly be due to presence of other viruses in the leaf samples that were not involved in the study. In the present study, specific primers targeting the viral coat protein of the CMBs were used.

Through nucleotide sequence analyses, it was revealed that both ACMV and EACMV from Unguja and Pemba Islands are more closely related to isolates from neighbouring countries such as Democratic Republic of Congo, Kenya and Uganda. The same trend was also shown in cluster analysis. This observation may be due to the fact that cassava is propagated by cuttings, thus exchange of planting materials across the neighbouring countries might influence the spread of ACMV and EACMV. Various studies reported the practice of farmer to farmer exchange of cassava planting materials in sub-Saharan African countries and its influences on spread of ACMV and EACMV across the borders (Fondong et al. 2000, Ndunguru et al. 2005, Harimalala et al. 2015). On the other hand, one ACMV isolate from the present study showed similarity to ACMV reported in Madagascar. The present findings are in agreement with previous findings documented by Fondong et al. (2000) that, ACMV are widely distributed in many other parts of Africa. In addition, two of the identified EACMV in this study were similar to those of EACMV reported in Madagascar and Cameroon. This observation is not surprising since Ndunguru et al. (2005) documented the presence of East African cassava mosaic Cameroon virus (EACMCV) in Tanzania especially in Ruvuma, Tanga, Pwani and Mara regions. These findings may also be due to the growing movements of viruses around the world through increased globalization of trade such as plants and plant products in and out of their mother countries. Alabi et al. (2008) documented the effects of world trade of plants and plant products on the spread of CMBs (ACMV and EACMV) from their centres of domestication to the different parts of the world. Several other studies reported the effects of world trade on the spread of CMBs (Appiah et al. 2012, Asala et al. 2014).

Based on the results obtained from Blastn similarities and phylogenetic analysis, the present study to our knowledge reports for the first time the occurrence of ACMV in Datura stramonium (Solanaceae), Solanum melongena (Solanaceae) and Solanum incanum (Solanaceae) and EACMV in Senna occidentalis, Sida acuta (Malvaceae) and Ricinus communis (Euphorbiaceae) in Tanzania. These non-crop plants are common and widely distributed throughout Unguja and Pemba Islands as well as other parts of Tanzania mainland; therefore, proper management and control of these non-crop plant species are very important since they might serve as sources of virus inocula for the spread of CMBs to and within cassava fields. Some of the non-crop plant species which were identified as reservoirs of CMBs in the present study have been previously reported elsewhere. For example ACMV was detected in Datura stramonium and Solanum melongena (Bock et al. 1978, Fauquet and Fargette 1990) while EACMV was detected from Senna occidentalis and Ricinus communis (Ogbe et al. 2006, Alabi 2008). However, the occurrence of ACMV in $S$. incanum and EACMV in Sida acuta might be the first time to be reported elsewhere. Further investigation is recommended to assess the infectivity of the CMBs isolated from these two non-crop plants on cassava.

\section{Conclusion}

Cassava mosaic begomoviruses (EACMV and ACMV) were identified in Datura stramonium, Solanum melongena, Solanum incanum, Senna occidentalis, Sida acuta and Ricinus communis non-crop plant species collected in Unguja and Pemba islands. Among the non-crop plants, S. incanum and 
S. acuta to the best of our knowledge had not been reported earlier as reservoirs of ACMV and EACMV, respectively. These non-crop plants can act as potential sources of primary inoculum of these viruses and thus play important roles in their persistence and spread of CMD to cassava farms. Therefore, efficient management of ACMV and EACMV in cassava fields should also focus on control and managements of $S$. incanum and $S$. acuta non-crop plants species. Further studies should be conducted on the identification of other plant viruses in non-crop plants so as to increase the efficiency of plant virus control and management. In order to understand if the CMBs isolated in this study can play roles in the transmission of CMD, the virus infectivity studies to the CMD susceptible cassava varieties are also recommended.

\section{Acknowledgements}

The authors are grateful to the Tanzania Agricultural Research Institute (TARI)Mikocheni for technical and materials support to the successful completion of this work.

\section{References}

Alabi OJ, Ogbe FO, Bandyopadhyay R, Kumar PL, Dixon AGO, Hughes J and Naidu RA 2008 Alternate hosts of African cassava mosaic virus, East African cassava mosaic and Cameroon virus in Nigeria. Arch. Virol. 153: 1743-1747.

Alemu K 2015 Detection of diseases, identification and diversity of viruses: $J$. Biol. Agric. Health. 5(1): 204-213.

Aloyce RC 2013 Development and evaluation of efficient diagnostic tools for cassava mosaic and cassava brown streak diseases. Master thesis, University of Witwatersrand, Johannesburg Republic of South Africa.

Appiah AS, Amoatey HM, Kiu GYP, Affu NT, EAzu E and Awush GR 2012 Spread of African cassava mosaic virus from manihot asculenta crant to physic nut (Jatropha curcas L) in Ghana. J. Phytol. 4: 31-37.

Asala S, Alegbejo MD, Kashina BD, Banwo OO and Shinggu CP 2014 Viruses in weeds in Dioscorea yam fields in Nigeria. Afr. Crop Sci. J. 22(2): 109-115.

Berrie LC, Rybicki EP and Rey ME 2001 Complete nucleotide sequence and host range of South African cassava mosaic virus: further evidence for recombination amongst begomoviruses. J. Genet. Virol. 82: 53-58.

Bisimwa E, Walangululu $\mathrm{J}$ and Bragard $\mathrm{C}$ 2012 Occurrence and distribution of cassava mosaic begomovirus related to agro-ecosystems in the Sud-Kivu Province, Democratic Republic of Congo. Asian J. Plant Pathol. 6: 1-12.

Bock KR 1994 The spread of African cassava geminivirus in coastal Kenya. Rev. Sci. 34: 92-101.

Bock KR, Guthrie EJ and Meredith G 1978 Distribution, host range, properties and purification of cassava latent virus, a geminivirus. Ann. Appl. Biol. 90: 361-367.

Bock KR and Woods RD 1983 Etiology of African cassava mosaic disease. Plant Dis. 67: 994-995.

Bock KR, Guthrie EJ and Figueiredo G 1981 A strain of cassava latent virus occurring in coastal districts of Kenya. Ann. Appl. Biol. 99: 151-159.

Bonfim K, Faria JC, Nogueira EO, Mendes EA and Aragão FJ 2007 RNAi-mediated resistance to Bean golden mosaic virus in genetically engineered common bean (Phaseolus vulgaris). Mol. Plant Microbiol. Interact. 20: 717-726.

Bosque-Pérez NA and Eigenbrode SD 2011 The influence of virus-induced changes in plants on aphid vectors: insights from luteovirus pathosystems. Virus Res.159: 201-205.

Burban C, Fishpool LDC, Fauquet C, Fargette D and Thouvenel JC 1992 Host-associated biotypes within West African populations of the whitefly Bemisia tabaci (Genn.), (Hom.Aleyrodidae). J. Appl. Entomol. 113: 416-423.

Cuénoud P, Savolainen V, Chatrou LW, Powell M, Grayer RJ and Chase MW 2002 Molecular phylogenetics of Caryophyllales based on nuclear 18S rDNA and plastid $r b c L$, atpB, and 
matK DNA sequences. Am. J. Bot. 89: 132-144.

Donaire DL, Wang Y, Gonzalez-Ibeas D, Mayer K, Aranda MA and Llave C 2009 Deep-sequencing of plant viral small RNAs reveals effective and widespread targeting of viral genomes. J. Virol. 392: 203-214.

Eni AO and Fasasi DK 2013 Molecular detection of two cassava Begomoviruses in some parts of Southern Nigeria. Afr. J. Agric. Res. 8(16): 1350-1353.

FAOSTAT 2019 Food and Agriculture Organisation of the United Nations, Rome, Italy. Available online at http://faostat3.fao.org. Accessed on $14^{\text {th }}$ February, 2021.

Fauquet C and Fargette D 1990 African cassava mosaic virus: Etiology, epidemiology and control. Plant Dis. 74:404-411.

Felsenstein J 1985 Confidence limits on phylogenies: An approach using the bootstrap. Evol. 39(4): 783-791.

Fondong VN, Pita JS, Rey ME, de Kochko A, Beachy RN and Fauquet CM 2000 Evidence of synergism between African cassava mosaic virus and a new doublerecombinant geminivirus infecting cassava in Cameroon. J. Genet. Virol. 81: 287297.

Hahn SK, Terry ER and Leuschner K 1980 Breeding cassava for resistance to cassava mosaic disease. Euphytica 29: 673-683.

Harimalala M, Chiroleu F, Giraud-Carrier C, Hoareau M, Zinga I, Randriamampianina JA, Velombola S, Ranomenjanahary S, Andrianjaka A, Reynaud B, Lefeuvre P and Lett JM 2015 Molecular epidemiology of cassava mosaic disease in Madagascar. Plant Pathol. 64: 501-507.

Kidulile CE, Miinda AE, Alakonya AE and Ndunguru JC 2018 Efficacy of chemotherapy and thermotherapy in elimination of East African cassava mosaic virus from Tanzanian cassava landrace. J. Phytopathol. 166(10): 739745.

Kress WJ, Erickson DL, Jones FA, Swenson NG, Perez R, Sanjur O and Bermingham E 2009 Plant DNA barcodes and a community phylogeny of a tropical forest dynamics plot in Panama. Proc. Nat. Acad. Sci. 106: 18621-18626.

Kreuze JF, Perez A, Untiveros M, Quispe D, Fuentes S, Barker I and Simn R 2009 Complete viral genome sequence and discovery of novel viruses by deep sequencing of small RNAs: a generic method for diagnosis, discovery and sequencing of viruses. Virol. 388: 1-7.

Kyalo D, Amratia P, Mundia CW, Mbogo CM, Coetzee M and Snow RW 2017 A geo-coded inventory of anophelines in the Afrotropical Region south of the Sahara: 1898-2016. Wellcome Open Research 2: 57.

Legg JP and Raya M 1998 Survey of cassava virus diseases in Tanzania. Int. J. Pest Manage. 44: 17-23.

Legg J, Somado EA, Barker I, Beach L, Ceballos H, Cuellar W, Elkhoury W, Gerling D, Helsen, J, Hershey C and Jarvis A 2014 A global alliance declaring war on cassava viruses in Africa. Food Security 6(2): 231-248.

Lodhi MA, Ye GN, Weeden NF and Reisch BI 1994 A simple and efficient method for DNA extraction from grapevine varieties and Vitis species. Plant Mol. Biol. Rep. 12: 6-13.

Marwal A, Prajapat R and Gaur RK 2014 In silico recombination analysis of DNA-A sequence from begomovirus reported in India: This identified recombinant is the evolution from other viruses prevailing at different geographical region of Pakistan and China. Int. J. Curr. Microbiol. App. Sci. 3(2): 489-497.

McIntyre C and Shand S 2006 Zanzibar: Pemba-Mafia. $6^{\text {th }}$ Ed, The Globe Pequot Press, Guilford.

Ndunguru J, Legg JP, Aveling TAS, Thompson G and Fauquet CM 2005 Molecular biodiversity of cassava begomoviruses in Tanzania: Evolution of cassava geminiviruses in Africa and evidence for East Africa being a center of diversity of cassava geminiviruses. Virol. J. 2(21): 1-23. 
NSCACS 2012 National Sample Census of Agriculture, Crop Sector-Zanzibar Report URT.

Ogbe FO, Dixon AGO, Hughes JA, Alabi OJ and Okechukwu R 2006 Status of cassava begomoviruses and their new natural hosts in Nigeria. Plant Dis. 90: 548-553.

Pita JS, Fondong VN, Sangare A, Otim-Nape GW, Ogwal S and Fauquet CM 2001 Recombination, pseudorecombination and synergism of geminiviruses are determinant keys to the epidemic of severe cassava mosaic disease in Uganda. J. Gener. Virol. 82: 655-665.

Power AG and Mitchell CE 2004 Pathogen spillover in disease epidemics. Am. Naturalist 164: S79-S89.

Sanger F, Nicklen S and Coulson AR 1977 DNA sequencing with chain terminating inhibitors. Proc. Natl. Acad. Sci. 74: 54635467.

Sewando PT 2012 Urban markets-linked cassava value chain in Morogoro rural district, Tanzania. J. Sustain. Dev. Afr. 14(3): 283-300.

Shoka IH 2015 Contribution of agriculture to the economic growth of Zanzibar: Master thesis, University of Mzumbe.

Sseruwagi P, Sserubombwe WS, Legg JP, Ndunguru J and Thresh JM 2004 Methods of surveying the incidence and severity of cassava mosaic disease and whitefly vector populations on cassava in Africa: a review. Virus Res. 100: 129-142.

Storey HH and Nichols RFW 1938 Studies on the mosaic of cassava. Ann. Appl. Biol. 25: 790-806.

Tamura K, Stecher G, Peterson D, Filipski A and Kumar S 2013 MEGA6: molecular evolutionary genetics analysis version 6.0. Mol. Biol. Evol. 30: 2725-2739.

Thompson JD, Higgins DG and Gibson TJ 1994 CLUSTAL W Improving the sensitivity of progressive multiple sequence alignment through sequence weighting, position-specific gap penalties and weight matrix choice. Nucleic Acids Res. 22: 4673-4680.

Udayashankar AC, Nayaka SC, Niranjana SR, Mortensen CN and Prakash HS 2012 Immunocapture RT-PCR detection of Bean common mosaic virus and strain blackeye cowpea mosaic in common bean and black gram in India. Arch. Phytopathol. Plant Protect. 45(13): 15091518.

Varsani A, Navas-Castillo J, Moriones E, Hernández-Zepeda C, Idris A, Brown JK, Zerbini FM and Martin DP 2014 Establishment of three new genera in the family Geminiviridae: Becurtovirus, Eragrovirus and Turncurtovirus. Arch. Virol. 159(8): 2193-2203. 